\title{
Effect of Compartment Bunding Systems to Enhance the Productivity and Profitability Using Partial Mechanization for Chickpea under Semi Arid Region of Northern Karnataka
}

\author{
Umarfarooque Momin ${ }^{1}$, Ramesh Beerge ${ }^{2^{*}}$, Basavaraj Jamakhandi², \\ Maheshwar M. Shirahatti ${ }^{1}$
}
${ }^{1}$ AICRP for Dryland Agriculture, Regional Agricultural Research Station, Vijayapura, University of Agricultural Sciences Dharwad, India
${ }^{2}$ College of Agriculture Vijayapura, University of Agricultural Sciences, Dharwad, India

*Corresponding author

\section{A B S T R A C T}

\begin{tabular}{l} 
K e y w o r d s \\
$\begin{array}{l}\text { Compartment } \\
\text { bunding, In-situ } \\
\text { moisture } \\
\text { conservation, } \\
\text { Mechanization, } \\
\text { Water productivity }\end{array}$ \\
\hline Article Info \\
$\begin{array}{l}\text { Accepted: } \\
\text { 20 January } 2021 \\
\text { Available Online: } \\
\text { 10 February } 2021\end{array}$
\end{tabular}

Improving the socio-economic status of the farmers and sustainable food grain production is an important issue in semi-arid regions. Shrinking natural resources due to land degradation, urbanization, climate change, scanty and uneven distribution of rainfall lead to a reduction in the productivity of dryland crops. Hence, the study was conducted on the effect of different sizes of compartment bund system (in-situ moisture conservation) with partial mechanized methods for increasing productivity and profitability of chickpea crop under vertisols of the semi-arid region of northern Karnataka. Chickpea was grown in the rabi season under a compartment bund system of different sizes (in-situ moisture conservation)of $2 \times 2 \mathrm{~m}$ and $3 \times 3 \mathrm{~m}$ were found best practices for efficient management of in-situ moisture content in vertisols which significantly increases the grain yield, water use efficiency, and water productivity. In addition to this, the compartment bund system with partial mechanization in various operations i.e., from land preparation to harvesting and threshing increases the farm income, in terms of gross return, the net return, and B: C ratio by reducing input cost. About 30 to 60 percent of chickpea yield was achieved by adopting compartment bunds with partial mechanical methods in rainfed regions.

\section{Introduction}

From a global perspective, water conservation is playing a key role in increasing water productivity of dryland crops especially in rainfed areas of the Semi-Arid Tropical (SAT) region. From a regional point of view, unpredicted or erratic distribution of rainfall, reduction of rainy days, increasing the intense rainfall pattern results in a higher runoff, soil erosion, moreover shift in sowing and harvesting periods will lead to a reduction in yield of the crops grown during rabi season. About 73 percent of the area is available for cultivation of crops in the world and in India, about 60 percent of the area is available for cultivation of crops under rainfed condition, which contributes to 40 percent of the total 
food production. In India, crops like sorghum (93\%), pearl millet (94\%), maize (79\%), pulses $(87 \%)$, oilseeds $(76 \%)$ and cotton (64\%) were grown under dryland conditions and these crops will act as a source of fodder for a major livestock production system (Singh et al., 2007; Somasundaram et al., 2014). After the implementation of the World Trade Organization (WTO) and Intellectual Property Rights (IPR) on account of globalization of agriculture, pulse crops play a key role in nutritional security by meeting protein requirements for diet. Enhancement of productivity of cropping systems through natural resources with a crop rotation with pulses increases the fertility of soils and yields in cereals and oilseeds (Tripathi, 2010; Gan et al., 2002). Besides, the cultivation of pulse crops increases the profitability through higher net returns and also additional profit due to lower cost of production (Curforth et al., 2013; Gowda et al., 2013). Production of field crops that are rich in proteins is very important for nutritional security (Gowda et $a l ., 2013)$. India is the largest pulse producing country in the world which nearly produces $25 \%$ of the world's share (IIPR, 2011). In India, production of pulse crops was about 17.21million tonnes from an area of 24.78 million hectares (Nadarajan, 2013) and expected to produce 32 million tonnes by 2030 to meet projected demand (Anonymous, 2011). Chickpea was the major pulse crop cultivated during the winter season in the Vertisols of south India. With the growing population, per capita availability of soil and water resources are shrinking day by day, and thereby increasing scarcity of crop production in the country highlights the importance of optimizing its use. Inadequate availability of water resources for agriculture due to erratic rains and high evapotranspiration affects the increasing demand for water for agriculture, domestic and industrial use. The issues concerning land degradation and loss of soil fertility due to land-use intensification and climate change the availability of water and agricultural land is increasingly becoming a scarce resource for food production, the need for innovation in land-use efficiency and to enhance crop productivity from water resources. Moreover, efficient utilization of rainwater is of great concern for the improvement and sustainability of agriculture in the dryland agroecosystem. Besides, the presence of black soils with high clay content and low infiltration rate results in 10 to $30 \%$ runoff with loss of fertile top-soil. In such conditions, in-situ rainwater conservation techniques can enhance the crop yields especially in drought conditions (Patil and Sheelavantar, 2004; Rao et al, 2007; Venkateswarlu and Shanker, 2009). With the aim of harvest every drop of rainwater in situ and increase the water use efficiency for higher crop productivity. Hence in rainfed areas, the in-situ rainwater harvesting in the form of the compartmental bunding system has tremendous scope for increasing the productivity of the rainfed area. Compartmental bunding was used to conserve the rainwater in situ, recharge soil profile uniformly reduces runoff, soil and nutrient losses, and increases crop yields on a sustainable basis, but due to intensive labour requirement compartment bunding system was limited scope for its adoption by the growers. Also, high energy investment in terms of mechanical energy for the formation of compartment bunds and require more investment in the hiring of bullock pairs and farm labours. Moreover, due to labour scarcity and increasing the labour cost, farmers are facing acute problems for their agricultural production. Therefore, there is a need for alternate technologies to address the aforementioned issues, especially in field crops. Mechanization for the cultivation of field crops is an alternative to increase the farm income by reducing input cost and drudgery on labour. 
In this context, a study was conducted for two years (2017-19) at Regional Agricultural Research Station, Vijayapura, Karnataka, India to know the performance of partially mechanization along with different sizes of compartment bunds as in-situ moisture conservation on chickpea yield, water productivity and economic befits comparison with the traditional methods of cultivation.

\section{Materials and Methods}

Study area: A three year (2017-2019) field experiment was done to study the effect of various sizes of compartment bunds constructed by using tractor-drawn and bullock drawn implements on water productivity under chickpea cultivation at Dryland Agricultural Research Centre, Regional Agricultural Research Station (RARS), Vijayapura (Fig. 1). The experimental site was located at Karnataka (India) $16^{\circ} 49^{\prime}$ North latitude and $75^{\circ} 43^{\prime}$ East longitude at an altitude of $593.6 \mathrm{~m}$ above mean sea level. Vijayapura district is situated in agro-climatic zone-3 of the northern part of Karnataka. Under zone-3, the majority of the farming system situated in a rainfed condition with arid to semi-arid climate. The average rainfall was about $594.40 \mathrm{~mm}$ with an average of 30 rainy days in a year.

The normal maximum and minimum temperatures were experienced in the region about $32.8^{\circ} \mathrm{C}$ and $20.8{ }^{0} \mathrm{C}$ respectively with $71.8 \%$ relative humidity during the morning and $44 \%$ relative humidity in the afternoon onwards. The soil is a medium black clay (16.2\% coarse sand, $6.3 \%$ fine sand, $13.2 \%$ silt, and $54.3 \%$ clay) type. The depth of productive soil ranges from 45 to $60 \mathrm{~cm}$ having a bulk density of $1.43 \mathrm{~g} . \mathrm{cm}^{-1}$ and maximum water holding capacity of $17.6 \%$. The infiltration capacity of the soil is moderate ( 0.8 to $1.0 \mathrm{~cm} \mathrm{hr}-1)$ and $\mathrm{pH}$ is about 8.5 .
Chickpea (JG-11) has been grown during Rabi season (October to January) in the year (2017-2019) under different sizes of compartment bund system. In this experiment, the main treatments are $\mathrm{M}_{1}$-Partial mechanized method of cultivation and $\mathrm{M}_{2^{-}}$ Traditional method of and sub-treatment are $\mathrm{T}_{1^{-}}$6x6m size compartment bunds, $\mathrm{T}_{2^{-}} 3 \times 3 \mathrm{~m}$ size compartment bunds, $\mathrm{T}_{1}-4.5 \times 4.5 \mathrm{~m}$ size compartment bunds, $\mathrm{T}_{1^{-}} \quad 2 \times 2 \mathrm{~m}$ size compartment bunds, $\mathrm{T}_{5^{-}}$No compartment bunds (control) with three replications.

Farm operations such as plouging, sowing, inter cultivation, insects and pest control, harvesting, and threshing were performed using the partially mechanized and traditional methods. The formation of different sizes of compartment bunds for in-situ rainwater harvesting was done by using tractor and bullock drawn bund former was shown in Fig. 2 and 3. In the case of a tractor-drawn compartment bund former, the treatment $\mathrm{M}_{1} \mathrm{~T}_{4}$ was done by using double bottom bund formers, and other sizes are done by using a single bottom bund former. Time was recorded for each operation to estimate the field capacity $\left(h a h r^{-1}\right.$.) for all the treatments. Tools and implements are used in various farm operations were listed in table no. 1 for both mechanized and traditional farming methods. Spacing was used and for the other compartment bund system, a single bottom bund former was used (Fig. 4 and 5).

An operation-wise input energy source for cultivation of chickpea was estimated by multiplying energy coefficients with the number of inputs used such as farm labours, farm machinery, seeds, fertilizers, pesticides, and chemicals, etc., as shown in table-1.The estimation of input energy was calculated in terms of direct, indirect, renewable, and nonrenewable sources energies (Alam et al., 2005). The input materials such as seeds, fertilizers, manure, chemicals, machinery 
were used as indirect sources of energy. Whereas, human labours, and fuel (petrol or diesel) were used as a direct energy source. The sources such as fuels, chemicals, fertilizers, and farm machinery were categorized as non-renewable energy sources. Whereas the input sources like human labour, seeds, and manures were categorized as input renewable energy sources. The energy efficiency in various treatments was evaluated by the energy ratio between output and input energy used in the cultivation of chickpea. The input and output energy was estimated by the coefficient of energy equivalent for human labour, farm machinery, fuel, fertilizers, pesticides, herbicides, fungicides, input seeds, and yield values of chickpea.

The different energy indices such as energy use efficiency (EUE), energy productivity (EP), specific energy (SE), and net energy were estimated using the following methods.

Energy ratio or energy use effficiency $=\frac{\text { Total energy output }\left(\mathrm{MJ} \mathrm{ha}^{-1}\right)}{\text { Total energy input }\left(\mathrm{MJ} \mathrm{ha} \mathrm{h}^{-1}\right)}$

Energyproductivity $\left(\mathrm{kgMJ}^{-1}\right)=\frac{\text { Grainyield }\left(\mathrm{kgha}^{-1}\right)}{\text { TotalEnergyinput }\left(\mathrm{kg} \mathrm{ha}^{-1}\right)}$

Specific energy $\left(\mathrm{MJ} \mathrm{kg}^{-1}\right)=\frac{\text { Total Energy input }\left(\mathrm{kgha}^{-1}\right)}{\text { Grain yield }\left(\mathrm{kg} \mathrm{ha}^{-1}\right)}$

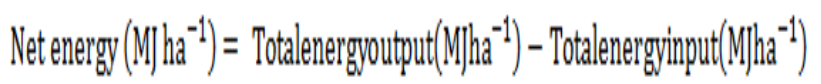

The Meteorological data was collected from All India Coordinated Research Project on Agro-Meteorology Station (ACRPAM), Regional Agricultural Research Station, Vijayapura. The rainfall and evapotranspiration occur from 2017 to 2019 were presented in figure 6 . The soil samples were collected to study moisture distribution patterns in various sizes of the compartment bund system in which soil moisture content was determined by using the gravimetric method (Reynolds, 1970). Rainwater use efficiency was estimated for various sizes of compartment bund systems which can be expressed as the economic yield divided by the seasonal crop water use i.e., seasonal evapotranspiration (Zwarat et al., 2004; Geerts et al., 2009), while the rainwater productivity was estimated which is expressed as the gross return from economic yield divided by the seasonal crop water use i.e. seasonal evapotranspiration(Turner et al., 2004).

Rainwater use efficiency $\left(\mathrm{kg} \mathrm{ha}^{-1} \mathrm{~mm}^{-1}\right)=\frac{\text { Bconomic yield }\left(\mathrm{kgha}^{-1}\right)}{\text { Seasonal evapotrangpiration }(\mathrm{mm})}$

Water productivity $\left(R s \mathrm{ha}^{-1} \mathrm{~mm}^{-1}\right)=\frac{\text { Gross Return from economicyield }\left(\mathrm{Rs} \mathrm{ha} \mathrm{h}^{-1}\right)}{\text { Seasonal evapotranspiration }(\mathrm{mm})}$

The effect of compartment bund system on insitu water conservation was assessed through the efficiency of moisture conservation method using the following relation (Kannan et al., 2010)

$E=\frac{M_{2} \cdot 100}{\left(M_{1}+R\right) \text { or } S_{c} \text { whichever is less }}(7)$

Where, $E=$ efficiency of moisture conservation $(\%), M_{1}=$ moisture at the beginning of the crop period $(\mathrm{mm}), M_{2}=$ moisture content at the end of crop period $(\mathrm{mm}), R=$ rainfall received during crop period $(\mathrm{mm})$ and $S_{c}=$ storage capacity of the soil $(\mathrm{mm})$.

Comparison of effects of various sizes of compartment bunds (in-situ water conservation) for chickpea cultivation - an economical analysis was used by using economic tools such as cost of cultivation, net return and Benefit-Cost Ratio (B:C ratio) (Demircan et al., 2006; Ozkan et al., 2004). Split plot design technique was used to analyze the effect of different sizes of 
compartment bund systems of tractor and bullock drawn implements on the economic yield of chickpea.

\section{Results and Discussion}

\section{The energy input for the production of Chickpea}

The energy requirement for the formation of the compartment bund was found 894.28 MJ $h a^{-1}$ i.e. $7.30 \%$ of total input energy of 12244.56 $\mathrm{MJ} \mathrm{ha}^{-1}$, which was observed in bund size of $2 \times 2 \mathrm{~m}\left(\mathrm{M}_{1} \mathrm{~T}_{4}\right)$ of the compartment bunds formed by the tractor-drawn implement. Whereas, $43.24 \mathrm{MJ}$ of $0.72 \%$ of total input energy was $6800.84 \mathrm{MJ} \mathrm{ha}^{-1}$ in case of treatment $4.5 \times 4.5 \mathrm{~m}\left(\mathrm{M}_{2} \mathrm{~T}_{3}\right)$ size of compartment bund formed by using bullock drawn implement. Moreover, the highest input energy was $13625.01 M J \mathrm{ha}^{-1}$ and the lowest was $7948.31 \mathrm{MJ} \mathrm{ha}^{-1}$ were observed in $\mathrm{M}_{1} \mathrm{~T}_{2}$ and $\mathrm{M}_{1} \mathrm{~T}_{5}$ treatments respectively. Whereas 6800.84 MJ $\mathrm{ha}^{-1}$ and 5973.84 MJ ha ${ }^{l}$ of the highest and lowest input energy were observed in $\mathrm{M}_{2} \mathrm{~T}_{4}$ and $\mathrm{M}_{2} \mathrm{~T}_{3}$ respectively.

Highest and lowest input energy required for the cultivation of chickpea under various treatment were found highly fluctuated due to inter cultivation and weed management operations. Operation-wise and sources-wise summary of energy input used in the cultivation of chickpea under mechanized and traditional methods were presented in Table. $3,4,5$, and 6 .

The input energy in the form of direct energy was observed highest in $\mathrm{M}_{1} \mathrm{~T}_{2}$ treatment (5766.93MJ $h \mathrm{a}^{-1}$ ) while lowest in $\mathrm{M}_{2} \mathrm{~T}_{3}$ (1196.45 MJ $h a^{-1}$ ) treatment and indirect energy was observed highest in $\mathrm{M}_{1} \mathrm{~T}_{2}$ treatment and lowest in $\mathrm{M}_{2} \mathrm{~T}_{3}$ treatment i.e. 7858.08 $M J \quad h a^{-1}$ and $4777.40 \quad M J \quad h a^{-}$ ${ }^{l}$ respectively. In the form of renewable energy highest input was observed in $\mathrm{M}_{2} \mathrm{~T}_{4}$ (1646.44 $\left.M J \mathrm{ha}^{-1}\right)$ and the lowest was $\mathrm{M}_{1} \mathrm{~T}_{1}(1072.72$
MJ $\left.h \mathrm{a}^{-1}\right)$. Moreover, the highest and lowest input energy was observed in $\mathrm{M}_{1} \mathrm{~T}_{2}(13625.01$ $\left.M J \quad h a^{-1}\right)$ and $\mathrm{M}_{2} \mathrm{~T}_{3} \quad\left(5973.84 \quad M J \quad h a^{-1}\right)$ respectively in the form of non-renewable energy source. The summary of input sources of direct, indirect, renewable, and nonrenewable energies for various sizes of compartment bund systems are presented in Table. 5.

The source-wise input quantity and its energy use such as human, fuel, farm machinery, tractor, bullock pair, fertilizers, insecticides, pesticides, and seed for various sizes of compartment bund systems were presented in table no.5 and 6. The input source such as human labour, farm machinery with tractor or bullock drawn implement, and chemicals required quantity were found highly fluctuated for inter cultivation, weed management, insects, and pest management. This is due to the natural condition of weed growth in the field, insects, and pest attach due to variation in the weather condition during growth stages of chickpea cultivation. The percent wise various sources wise input energy was presented in figure 7 .

Input energy was recorded to perform sowing and inner cultivation operations, while the lowest input energy requirement was recorded for threshing operation. The operation wise input energy requirements for various field operations were presented in table no. 4 and 5.

Particularly the input energy requirement for the formation of compartment bund under the partial mechanized system was recorded, 894.28 MJ $h a^{-1}$ which was highest in $\mathrm{M}_{1} \mathrm{~T}_{4}$ and 156.63 $\mathrm{MJ} h \mathrm{~h}^{-1}$ was recorded lowest in $\mathrm{M}_{1} \mathrm{~T}_{1}$ treatment. Whereas in the traditional system, 205.75 MJ $\mathrm{ha}^{-1}$ was recorded highest in $\mathrm{M}_{2} \mathrm{~T}_{4}$, and lowest in $\mathrm{M}_{2} \mathrm{~T}_{1}$ was $33.93 \mathrm{MJ}$ $h a^{-1}$. Operation-wise various input energy sources were presented in figure 8 . 


\section{Performance of partial mechanization and compartment bunding}

Performance of various farming systems under the compartment bund system was assessed through various factors, such as field capacity of tractor and bullock drawn farm implements, energy indices (Table no. 2 and 3 ), economical indicators, yield, water productivity and efficiency of moisture conservation methods. The effect of various sizes of compartment bunds on yield, economics, water use efficiency, water productivity, and efficiency of moisture conservation was presented in table no 8 and 9.

\section{Field capacity}

Different types of implements are used for various farm operations in partial mechanized and traditional cultivation methods for the preparation of different size of compartment bunds along with the field capacities were presented in table no. 8. It was observed that there is no significant difference in the input energy required for various sizes of compartment bunds for various operations. The highest field capacity was observed in partially mechanized system $\mathrm{M}_{1} \mathrm{~T}_{1} \quad(1.68$ $\left.h a . h r^{-1}\right)$ and lowest in $\mathrm{M}_{1} \mathrm{~T}_{4}\left(0.29 h a \cdot h r^{-1}\right)$ for the formation of compartment bunds in the field. Whereas, highest field capacity was observed for the formation of compartment bunds in $\mathrm{M}_{2} \mathrm{~T}_{1}\left(0.43 h a \cdot h r^{-1}\right)$ treatment and in case of the traditional method of cultivation the lowest field capacity was observed in $\mathrm{M}_{2} \mathrm{~T}_{4}\left(0.10 h a \cdot h r^{-1}\right)$ treatment.

Hence, the aforementioned results indicated that the field capacity of various operations can be increased by replacing manual methods with partial or full mechanization. Hence, Fully mechanized field operations increase input energies, and thereby, it increases the field capacity of various operations and without mechanized field, operations mean fewer input energies, and thereby, it reduces the field capacity of various operations.

\section{Energy productivity}

Energy productivity of partial mechanized and the traditional based different size of compartment bunds was evaluated. The results revealed that under a partial mechanized system higher energy efficiency of 5.20 was recorded with higher energy productivity $\left(0.15 \mathrm{~kg} \quad \mathrm{MJ}^{-1}\right)$ and specific energy (6.48 $M J \mathrm{~kg}^{-1}$ ) in $\mathrm{M}_{1} \mathrm{~T}_{2}$. Whereas, lower energy efficiency was recorded 2.18 with lower energy productivity $\left(0.06 \mathrm{~kg} M J^{-1}\right)$ and specific energy $\left(15.73 \mathrm{MJ} \mathrm{kg}^{-1}\right)$ under the partial mechanized system $\left(\mathrm{M}_{1} \mathrm{~T}_{3}\right)$ without compartment bunds. Meanwhile, under the traditional system of cultivation, a higher energy efficiency (3.80) was recorded with energy productivity and specific energy of $0.11 \mathrm{kgMJ}^{-1}$ and $8.93 \mathrm{MJ} \mathrm{kg}^{-1}$ respectively, in $\mathrm{M}_{2} \mathrm{~T}_{3}$. Lower energy efficiency was observed under the traditional system of cultivation in $\mathrm{M}_{2} \mathrm{~T}_{4}$ without compartment bunds i.e energy efficiency (2.07), energy productivity $(0.06 \mathrm{~kg}$ $M J^{-1}$ ), and specific energy (16.38 $\mathrm{MJ} \mathrm{kg}^{-}$ $\left.{ }^{1}\right)$. The net energy in the partial mechanized system for the treatment $\mathrm{M}_{1} \mathrm{~T}_{4}$ was recorded highest 26826.28MJ $h a^{-1}$ and followed by $\mathrm{M}_{2} \mathrm{~T}_{2}$ was $25800.84 M J ~ h a^{-1}$ respectively. The lower net energy was found in $\mathrm{M}_{1} \mathrm{~T}_{5}$ and $\mathrm{M}_{2} \mathrm{~T}_{4}$ i.e. $16673.88 M J \mathrm{ha}^{-1}$ and $11423.56 \mathrm{MJ}$ $h a^{-1}$ respectively in the partial and traditional mechanized system.

These results indicated that the higher energy input usage increases the field capacity of particular field operations, thereby reduces the time required to complete the particular field operation. In addition to this, a partial mechanized system along with moisture conservation method will help to increase crop productivity (yield) and other benefits such as water use efficiency, water productivity, and net income. 
Effect of in-situ moisture conservation through compartment bunds

In this experiment, the compartment bund system was adopted as an in-situ moisture conservation technique. Statistical analysis indicated that in a compartment system $\mathrm{M}_{1} \mathrm{~T}_{4}$ treatment was found a sign with the highest yield of $1341.02 \mathrm{~kg} \mathrm{ha} \mathrm{h}^{-1}$ and water use efficiency of $7.08 \mathrm{~kg} \mathrm{ha} \mathrm{mm}^{-1}$, water productivity of Rs. $264 \mathrm{ha}^{-1} \mathrm{~mm}^{-1}$. Hence, $\mathrm{M}_{1} \mathrm{~T}_{4}$ was significantly highest as compared to other treatments. Moisture conservation efficiency was also highest in M1T4 (64.84 $\%)$ followed by M2T2 (63.38 \%) and M2T4 $(62.58 \%)$. There was an insignificant difference in partial mechanized and traditional systems of cultivation in terms of water use efficiency, water productivity, and efficiency of moisture conservation methods. But due to in-situ moisture conservation such as the formation of compartment bund of different sizes revealed that, as the bund size reduces and thereby it increases the crop yield, water use efficiency, water productivity and efficiency of moisture conservation method. In both, the system of cultivation i.e. partial mechanized and traditional cultivation method: the compartment bund size of $2 \times 2 \mathrm{~m}$ and $3 \times 3 \mathrm{~m}$ were recorded higher yield, higher water use efficiency, higher water productivity, and higher efficiency of conservation method. The results revealed that average yield was increased to $61 \%$ in $2 \times 2 \mathrm{~m}$ size of compartment bunds and $30 \%$ in $3 \times 3 \mathrm{~m}$ size of compartment bunds as compared to the average yield of control (Without compartment bunds). Similarly, this result was supported by the study of the Bundelkhand region of Northern Indian states revealed a higher chickpea yield when the crop was sown during the winter season in higher moisture content (Narain et al., 2014). Also, the chickpea yield was improved in a different land configuration such as furrow raised beds of $60 \mathrm{~cm}$ width was effective in conserving soil moisture to enhance the crop productivity (Mishra et al., 2012). In addition to this, Chickpea yield was found $43.90 \%$ higher in the compartment bund size of $10 \mathrm{x}$ $10 \mathrm{~m}$ under vertisols of the Bellari region of Southern India as compared to farmers' practice (Patil et al., 2016).

Table.1 Tools and implements used in the farm operations

\begin{tabular}{|c|c|c|c|c|c|}
\hline \multirow{2}{*}{$\begin{array}{l}\text { Sl. } \\
\text { No }\end{array}$} & \multirow{2}{*}{$\begin{array}{l}\text { Particulars of } \\
\text { field operations }\end{array}$} & \multicolumn{2}{|c|}{ Partial mechanized system } & \multicolumn{2}{|c|}{ Traditional system } \\
\hline & & $\begin{array}{c}\text { Type of } \\
\text { implement }\end{array}$ & $\begin{array}{l}\text { Power } \\
\text { source }\end{array}$ & $\begin{array}{c}\text { Type of } \\
\text { implement }\end{array}$ & $\begin{array}{l}\text { Power } \\
\text { source }\end{array}$ \\
\hline 1. & Ploughing & MB plough & Tractor & MB plough & Tractor \\
\hline 2. & $\begin{array}{l}\text { Compartment } \\
\text { bunding }\end{array}$ & Bund former * & Tractor & Bund former & Bullock pairs \\
\hline 3. & Harrowing & Blade harrow & Tractor & Blade harrow & Bullock pairs \\
\hline 4. & Sowing & $\begin{array}{l}\text { Seed cum } \\
\text { fertilizer drill }\end{array}$ & Tractor & $\begin{array}{l}\text { Seed cum } \\
\text { fertilizers drill }\end{array}$ & Bullock pairs \\
\hline \multirow[t]{3}{*}{5.} & \multicolumn{3}{|l|}{ Intercultivation. } & & \\
\hline & $1^{\text {st }}$ weeding & $\begin{array}{l}\text { portable power } \\
\text { cultivator }\end{array}$ & $\begin{array}{l}\text { Small petrol } \\
\text { engine }\end{array}$ & $\begin{array}{l}\text { Animal drawn } \\
\text { Hoe }\end{array}$ & Bullock pairs \\
\hline & $2^{\text {nd }}$ weeding & $\begin{array}{l}\text { power tiller } \\
\text { operated sweep } \\
\text { cultivator }\end{array}$ & Power tiller & $\begin{array}{l}\text { WHEEL HOE } \\
\text { (cycle weeder) }\end{array}$ & Manual \\
\hline
\end{tabular}




\begin{tabular}{|c|c|c|c|c|c|}
\hline & $3^{\text {rd }}$ weeding & $\begin{array}{l}\text { WHEEL HOE } \\
\text { (cycle weeder) }\end{array}$ & Manual & $\begin{array}{l}\text { Animal drawn } \\
\text { Hoe }\end{array}$ & \\
\hline \multirow[t]{3}{*}{6.} & \multicolumn{3}{|c|}{ Insects and pest management } & & \\
\hline & $1^{\mathrm{st}}$ spraying & $\begin{array}{l}\text { tractor mounted } \\
\text { sprayer }\end{array}$ & Tractor & Napsack sprayer & Manual \\
\hline & $\begin{array}{l}2^{\text {nd }} \text { chemical } \\
\text { spraying }\end{array}$ & $\begin{array}{l}\text { tractor mounted } \\
\text { sprayer }\end{array}$ & Tractor & Napsack sprayer & Manual \\
\hline 7. & Harvesting & $\begin{array}{l}\text { Sickel (one } \\
\text { person) }\end{array}$ & Manual & $\begin{array}{l}\text { sickel (one } \\
\text { person) }\end{array}$ & Manual \\
\hline 8. & $\begin{array}{l}\text { Threshing } \\
\text { operation }\end{array}$ & $\begin{array}{l}\text { Spike tooth } \\
\text { thresher }\end{array}$ & $\begin{array}{l}3-7.5 \mathrm{hp} \\
\text { Diesel } \\
\text { Engine }\end{array}$ & $\begin{array}{l}\text { Spike tooth } \\
\text { thresher }\end{array}$ & $\begin{array}{l}3-7.5 \mathrm{hp} \\
\text { Diesel } \\
\text { Engine }\end{array}$ \\
\hline
\end{tabular}

* Formation of $2 \times 2 \mathrm{~m}$ size compartment bunds a double bottom bund former with 2-meter

Table.2 The energy equivalent of input and output used in the production of Chickpea

\begin{tabular}{|c|c|c|c|}
\hline Particulars & Units & $\begin{array}{c}\text { Energy } \\
\text { equivalent (MJ) }\end{array}$ & References \\
\hline \multicolumn{4}{|l|}{ Inputs : } \\
\hline \multicolumn{4}{|c|}{ 1. Mechanical energy } \\
\hline Human labour & hours & 1.96 & Erdalet al., 2007; Yousefi and Damghani, 2012 \\
\hline Bullock pair & hours & 10.1 & Chilur and Yadachi, 2017 \\
\hline Machines & hours & 62.7 & Erdalet al., 2007; Esengunet al., 2007 \\
\hline \multicolumn{4}{|c|}{ 2. Chemical Energy } \\
\hline \multicolumn{4}{|c|}{ i. Organic and inorganic Fertilizers } \\
\hline Nitrogen & $\mathrm{kg}$ & 60.60 & Chilur and Yadachi, 2017 \\
\hline Phosphorous & $\mathrm{kg}$ & 11.10 & Chilur and Yadachi, 2017 \\
\hline Potassium & $\mathrm{Kg}$ & 6.70 & Chilur and Yadachi, 2017 \\
\hline FYM & $\mathrm{kg}$ & 0.30 & Chilur and Yadachi, 2017 \\
\hline \multicolumn{4}{|l|}{$\begin{array}{l}\text { i. Plant } \\
\text { protections }\end{array}$} \\
\hline Chemicals & $\mathrm{kg}$ & 120 & Ozkanet al., 2007; Demircanet al., 2006 \\
\hline Water & $\mathrm{L}$ & 0.63 & Erdalet al., 2007; Esengunet al., 2007 \\
\hline \multicolumn{4}{|c|}{ 3. Bio-energy } \\
\hline Seeds & $\mathrm{kg}$ & 14.70 & Kitani, 1999; Salami et al., 2014 \\
\hline \multicolumn{4}{|l|}{ Outputs: } \\
\hline 1. Grain yield & $\mathrm{kg}$ & 17.70 & Kitani, 1999 ; Salami et al., 2014 \\
\hline 2. Stover yield & $\mathrm{Kg}$ & 12.50 & Shilphaet al., 2018 \\
\hline
\end{tabular}


Table.3 Operation wise energy inputs used in the cultivation of chickpea using partial mechanized method

\begin{tabular}{|c|c|c|c|c|c|c|c|c|c|c|c|}
\hline \multirow{2}{*}{$\begin{array}{l}\text { Sl. } \\
\text { No }\end{array}$} & \multirow[b]{2}{*}{ Particulars } & \multicolumn{2}{|c|}{$\mathbf{M}_{1} \mathbf{T}_{1}$} & \multicolumn{2}{|c|}{$\mathbf{M}_{1} \mathbf{T}_{2}$} & \multicolumn{2}{|c|}{$\mathbf{M}_{1} \mathbf{T}_{3}$} & \multicolumn{2}{|c|}{$\mathbf{M}_{1} \mathbf{T}_{4}$} & \multicolumn{2}{|c|}{$\mathbf{M}_{1} \mathbf{T}_{5}$} \\
\hline & & $\begin{array}{l}\text { Energy } \\
\text { (MJ) }\end{array}$ & $\begin{array}{c}\text { Energy } \\
(\%)\end{array}$ & $\begin{array}{l}\text { Energy } \\
(\mathbf{M J})\end{array}$ & $\begin{array}{c}\text { Energy } \\
(\%)\end{array}$ & $\begin{array}{l}\text { Energy } \\
\text { (MJ) }\end{array}$ & $\begin{array}{c}\text { Energy } \\
(\%)\end{array}$ & $\begin{array}{l}\text { Energy } \\
(\mathbf{M J})\end{array}$ & $\begin{array}{c}\text { Energy } \\
(\%)\end{array}$ & $\begin{array}{l}\text { Energy } \\
\text { (MJ) }\end{array}$ & $\begin{array}{c}\text { Energy } \\
(\%)\end{array}$ \\
\hline 1 & Ploughing & 776.67 & 8.26 & 747.99 & 5.49 & 704.13 & 7.20 & 892.18 & 7.29 & 553.58 & 6.96 \\
\hline 2 & $\begin{array}{l}\text { Formation of } \\
\text { compartmenet bunds }\end{array}$ & 156.63 & 1.67 & 884.23 & 6.49 & 262.61 & 2.69 & 894.28 & 7.30 & -- & -- \\
\hline 3 & $\begin{array}{l}\text { Land preparation for } \\
\text { sowing }\end{array}$ & 662.38 & 7.04 & 184.60 & 1.35 & 444.59 & 4.55 & 790.80 & 6.46 & 397.75 & 5.00 \\
\hline 4 & Sowing & 3944.60 & 41.94 & 3817.47 & 28.02 & 3676.88 & 37.62 & 3973.50 & 32.45 & 4143.02 & 52.12 \\
\hline 5 & $\begin{array}{l}\text { Intercultivation and weed } \\
\text { management }\end{array}$ & 3285.38 & 34.93 & 7168.75 & 52.61 & 4245.14 & 43.44 & 5095.98 & 41.62 & 2290.29 & 28.81 \\
\hline 6 & $\begin{array}{l}\text { Insects \& pest control } \\
\text { measures }\end{array}$ & 351.12 & 3.73 & 596.97 & 4.38 & 212.37 & 2.17 & 321.46 & 2.63 & 231.88 & 2.92 \\
\hline 7 & Harvesting & 137.53 & 1.46 & 141.58 & 1.04 & 142.99 & 1.46 & 141.87 & 1.16 & 129.03 & 1.62 \\
\hline 8 & Thresing & 90.31 & 0.96 & 83.42 & 0.61 & 84.70 & 0.87 & 134.49 & 1.10 & 202.76 & 2.55 \\
\hline
\end{tabular}

Table.4 Operation wise energy inputs used in the cultivation of chickpea using a traditional method

\begin{tabular}{|c|c|c|c|c|c|c|c|c|c|c|c|}
\hline \multirow{2}{*}{$\begin{array}{l}\text { Sl. } \\
\text { No }\end{array}$} & \multirow[b]{2}{*}{ Particulars } & \multicolumn{2}{|c|}{$\mathbf{M}_{2} \mathbf{T}_{1}$} & \multicolumn{2}{|c|}{$\mathbf{M}_{2} \mathbf{T}_{2}$} & \multicolumn{2}{|c|}{$\mathbf{M}_{2} \mathbf{T}_{3}$} & \multicolumn{2}{|c|}{$\mathbf{M}_{2} \mathbf{T}_{4}$} & \multicolumn{2}{|c|}{$\mathbf{M}_{2} \mathbf{T}_{5}$} \\
\hline & & $\begin{array}{l}\text { Energy } \\
\text { (MJ) }\end{array}$ & $\begin{array}{c}\text { Energy } \\
(\%)\end{array}$ & $\begin{array}{l}\text { Energy } \\
\text { (MJ) }\end{array}$ & $\begin{array}{c}\text { Energy } \\
(\%)\end{array}$ & $\begin{array}{l}\text { Energy } \\
\text { (MJ) }\end{array}$ & $\begin{array}{c}\text { Energy } \\
(\%)\end{array}$ & $\begin{array}{l}\text { Energy } \\
\text { (MJ) }\end{array}$ & $\begin{array}{c}\text { Energy } \\
(\%)\end{array}$ & $\begin{array}{l}\text { Energy } \\
\text { (MJ) }\end{array}$ & $\begin{array}{c}\text { Energy } \\
(\%)\end{array}$ \\
\hline 1 & Ploughing & 794.85 & 12.95 & 886.78 & 13.78 & 749.80 & 12.55 & 997.62 & 14.67 & 720.24 & 11.04 \\
\hline 2 & $\begin{array}{c}\text { Formation of compartmenet } \\
\text { bunds }\end{array}$ & 33.93 & 0.55 & 109.79 & 1.71 & 43.24 & 0.72 & 205.75 & 3.03 & & 0.00 \\
\hline 3 & Land preparation for sowing & 192.02 & 3.13 & 210.58 & 3.27 & 166.99 & 2.80 & 183.29 & 2.70 & 209.48 & 3.21 \\
\hline 4 & Sowing & 2893.56 & 47.13 & 2853.68 & 44.33 & 2976.23 & 49.82 & 3137.60 & 46.14 & 3391.97 & 51.97 \\
\hline 5 & $\begin{array}{c}\text { Intercultivation and weed } \\
\text { management }\end{array}$ & 1019.23 & 16.60 & 1093.77 & 16.99 & 905.79 & 15.16 & 974.11 & 14.32 & 923.18 & 14.15 \\
\hline 6 & $\begin{array}{c}\text { Insects \& pest control } \\
\text { measures }\end{array}$ & 978.67 & 15.94 & 1028.25 & 15.97 & 915.84 & 15.33 & 1052.36 & 15.47 & 1078.92 & 16.53 \\
\hline 7 & Harvesting & 136.93 & 2.23 & 150.77 & 2.34 & 138.38 & 2.32 & 143.41 & 2.11 & 131.07 & 2.01 \\
\hline 8 & Thresing & 90.31 & 1.47 & 103.46 & 1.61 & 77.59 & 1.30 & 106.69 & 1.57 & 71.60 & 1.10 \\
\hline
\end{tabular}


Table.5 Energy sources utilizing direct, indirect, renewable, and non-renewable energies in used cultivation of Chickpea

\begin{tabular}{|c|c|c|c|c|c|c|c|c|c|c|c|}
\hline \multirow{2}{*}{$\begin{array}{l}\text { Sl. } \\
\text { No }\end{array}$} & \multirow[b]{2}{*}{ Particulars } & \multicolumn{10}{|c|}{ Energy, MJ/ha } \\
\hline & & $\mathbf{M}_{1} \mathbf{T}_{1}$ & $\mathbf{M}_{2} \mathbf{T}_{1}$ & $\mathbf{M}_{1} \mathbf{T}_{2}$ & $\mathbf{M}_{2} \mathbf{T}_{2}$ & $\mathbf{M}_{1} \mathbf{T}_{3}$ & $\mathbf{M}_{2} \mathbf{T}_{3}$ & $\mathbf{M}_{1} \mathbf{T}_{4}$ & $\mathbf{M}_{2} \mathbf{T}_{4}$ & $\mathbf{M}_{1} \mathbf{T}_{5}$ & $\mathbf{M}_{1} \mathbf{T}_{5}$ \\
\hline 1 & Direct energy & 3231.38 & 1268.76 & 5766.93 & 1429.11 & 3042.46 & 1196.45 & 4514.81 & 1525.11 & 3024.72 & 1183.63 \\
\hline 2 & Indirect energy & 6173.24 & 4870.75 & 7858.08 & 5007.97 & 6730.95 & 4777.40 & 7729.75 & 5275.72 & 4923.59 & 5342.82 \\
\hline 3 & Renewable energy & 1072.72 & 1492.62 & 1101.01 & 1562.00 & 1150.48 & 1477.40 & 1274.64 & 1646.44 & 1194.54 & 1432.06 \\
\hline 4 & Non-renewable energy & 8331.90 & 4646.88 & 12524.00 & 4875.08 & 8622.93 & 4496.44 & 10969.93 & 5154.40 & 6753.77 & 5094.38 \\
\hline
\end{tabular}

Table.6 Sources wise energy inputs used in the cultivation of chickpea using partial mechanized method

\begin{tabular}{|c|c|c|c|c|c|c|c|c|c|c|c|}
\hline \multirow{2}{*}{$\begin{array}{l}\text { Sl. } \\
\text { No }\end{array}$} & \multirow[b]{2}{*}{ Particulars } & \multicolumn{2}{|c|}{$\mathbf{M}_{1} \mathbf{T}_{1}$} & \multicolumn{2}{|c|}{$\mathbf{M}_{1} \mathbf{T}_{2}$} & \multicolumn{2}{|c|}{$\mathbf{M}_{1} \mathbf{T}_{3}$} & \multicolumn{2}{|c|}{$\mathbf{M}_{1} \mathbf{T}_{4}$} & \multicolumn{2}{|c|}{$\mathbf{M}_{1} \mathbf{T}_{5}$} \\
\hline & & Inputs & $\begin{array}{c}\text { Energy } \\
\text { (MJ) }\end{array}$ & Inputs & $\begin{array}{c}\text { Energy } \\
(\mathbf{M J})\end{array}$ & Inputs & $\begin{array}{l}\text { Energy } \\
\text { (MJ) }\end{array}$ & Inputs & $\begin{array}{l}\text { Energy } \\
(\mathbf{M J})\end{array}$ & Inputs & $\begin{array}{c}\text { Energy } \\
(\mathrm{MJ})\end{array}$ \\
\hline 1 & Human Labours (Hours) & 157.31 & 308.32 & 196.74 & 385.61 & 176.98 & 346.88 & 222.82 & 436.74 & 161.96 & 317.44 \\
\hline 2 & Fuel (Lites) & 51.91 & 2923.06 & 95.57 & 5381.12 & 47.87 & 2695.58 & 72.42 & 4078.08 & 53.91 & 2707.28 \\
\hline 3 & $\begin{array}{l}\text { Farm Machinery and } \\
\text { Tractors (Hours) }\end{array}$ & 78.26 & 2875.91 & 108.40 & 4590.54 & 96.95 & 3763.39 & 107.99 & 4640.95 & 96.13 & 1420.44 \\
\hline 4 & Chemical Fertilizers (Kg) & 15.24 & 2477.26 & 11.39 & 2493.76 & 12.81 & 2104.26 & 7.75 & 2182.58 & 10.40 & 2550.43 \\
\hline 5 & Insecticides (Kg) & 0.28 & 56.38 & 0.29 & 58.37 & 0.30 & 59.70 & 0.34 & 68.32 & 0.38 & 75.62 \\
\hline 6 & Seed $(\mathrm{Kg})$ & 52.00 & 764.40 & 48.67 & 715.40 & 54.67 & 803.60 & 57.00 & 837.90 & 59.67 & 877.10 \\
\hline \multicolumn{2}{|c|}{ Total Input Energy (MJ) } & \multicolumn{2}{|c|}{9404.62} & \multicolumn{2}{|c|}{13625.01} & \multicolumn{2}{|c|}{ 9773.41 } & \multicolumn{2}{|c|}{12244.56} & \multicolumn{2}{|c|}{7948.31} \\
\hline \multicolumn{2}{|c|}{ Grain Yield Kg ha ${ }^{-1}$} & \multicolumn{2}{|c|}{837.31} & \multicolumn{2}{|c|}{920.73} & \multicolumn{2}{|c|}{803.07} & \multicolumn{2}{|c|}{1341.02} & \multicolumn{2}{|c|}{649.09} \\
\hline \multicolumn{2}{|c|}{ Output Energy } & \multicolumn{2}{|c|}{28393.96} & \multicolumn{2}{|c|}{31940.34} & \multicolumn{2}{|c|}{31537.11} & \multicolumn{2}{|c|}{34707.52} & \multicolumn{2}{|c|}{27217.00} \\
\hline \multicolumn{12}{|c|}{ Energy Indices: } \\
\hline \multicolumn{2}{|c|}{ Energy Efficiency } & \multicolumn{2}{|c|}{2.78} & \multicolumn{2}{|c|}{5.20} & \multicolumn{2}{|c|}{2.18} & \multicolumn{2}{|c|}{4.40} & \multicolumn{2}{|c|}{2.58} \\
\hline \multicolumn{2}{|c|}{ Energy productivity kg $\mathbf{M J}^{-1}$} & \multicolumn{2}{|c|}{0.08} & \multicolumn{2}{|c|}{0.15} & & & & & & 08 \\
\hline Spe & ific Energy MJkg-1 & & & & 48 & & & & & & 13 \\
\hline Net & Energy & 18 & .10 & $25 \varepsilon$ & 0.84 & 17 & 2.85 & 268 & 6.28 & $16 t$ & 3.88 \\
\hline
\end{tabular}


Table.7 Sources wise energy inputs used in the cultivation of chickpea using a traditional method

\begin{tabular}{|c|c|c|c|c|c|c|c|c|c|c|c|}
\hline \multirow{2}{*}{$\begin{array}{l}\text { Sl. } \\
\text { No }\end{array}$} & \multirow[b]{2}{*}{ Particulars } & \multicolumn{2}{|c|}{$\mathbf{M}_{2} \mathbf{T}_{1}$} & \multicolumn{2}{|c|}{$\mathbf{M}_{2} \mathbf{T}_{2}$} & \multicolumn{2}{|c|}{$\mathbf{M}_{2} \mathbf{T}_{3}$} & \multicolumn{2}{|c|}{$\mathbf{M}_{2} \mathbf{T}_{4}$} & \multicolumn{2}{|c|}{$\mathbf{M}_{2} \mathbf{T}_{5}$} \\
\hline & & Inputs & $\begin{array}{c}\text { Energy } \\
(\mathrm{MJ})\end{array}$ & Inputs & $\begin{array}{l}\text { Energy } \\
\text { (MJ) }\end{array}$ & Inputs & $\begin{array}{c}\text { Energy } \\
\text { (MJ) }\end{array}$ & Inputs & $\begin{array}{l}\text { Energy } \\
\text { (MJ) }\end{array}$ & Inputs & $\begin{array}{l}\text { Energy } \\
\text { (MJ) }\end{array}$ \\
\hline 1 & Human Labours (Hours) & 354.04 & 693.92 & 401.94 & 787.80 & 333.77 & 654.20 & 410.02 & 803.64 & 338.14 & 662.76 \\
\hline 2 & Fuel (Lites) & 10.21 & 574.83 & 11.39 & 641.31 & 9.63 & 542.24 & 12.81 & 721.47 & 9.25 & 520.87 \\
\hline 3 & $\begin{array}{l}\text { Farm Machinery and Bullock Pairs } \\
\text { (Hours) }\end{array}$ & 281.99 & 1981.82 & 302.36 & 2146.48 & 255.82 & 1788.25 & 293.59 & 2181.35 & 271.36 & 2002.85 \\
\hline 4 & Chemical Fertilizers $(\mathrm{Kg})$ & 10.99 & 2032.52 & 8.24 & 2022.95 & 12.81 & 2104.26 & 7.75 & 2182.58 & 11.29 & 2520.92 \\
\hline 5 & Insecticides $(\mathrm{Kg})$ & 0.29 & 57.71 & 0.32 & 64.34 & 0.31 & 61.69 & 0.35 & 68.99 & 0.25 & 49.75 \\
\hline 6 & Seed $(\mathrm{Kg})$ & 54.33 & 798.70 & 52.67 & 774.20 & 56.00 & 823.20 & 57.33 & 842.80 & 52.33 & 769.30 \\
\hline \multicolumn{2}{|c|}{ Total Input Energy (MJ) } & \multicolumn{2}{|c|}{6139.50} & \multicolumn{2}{|c|}{6437.08} & \multicolumn{2}{|c|}{$\mathbf{5 9 7 3 . 8 4}$} & \multicolumn{2}{|c|}{6800.84} & \multicolumn{2}{|c|}{6526.44} \\
\hline \multicolumn{2}{|c|}{ Grain Yield Kg ha ${ }^{-1}$} & \multicolumn{2}{|c|}{946.80} & \multicolumn{2}{|c|}{1019.44} & \multicolumn{2}{|c|}{774.69} & \multicolumn{2}{|c|}{1052.21} & \multicolumn{2}{|c|}{833.49} \\
\hline \multicolumn{2}{|c|}{ Output Energy } & \multicolumn{2}{|c|}{26472.44} & \multicolumn{2}{|c|}{45998.49} & \multicolumn{2}{|c|}{35713.36} & \multicolumn{2}{|c|}{22058.50} & \multicolumn{2}{|c|}{28701.18} \\
\hline \multicolumn{12}{|c|}{ Energy Indices: } \\
\hline \multicolumn{2}{|c|}{ Energy Efficiency } & \multicolumn{2}{|c|}{3.04} & \multicolumn{2}{|c|}{3.55} & \multicolumn{2}{|c|}{3.80} & \multicolumn{2}{|c|}{2.07} & \multicolumn{2}{|c|}{3.14} \\
\hline \multicolumn{2}{|c|}{ Energy productivity kg $\mathbf{M J}^{-1}$} & \multicolumn{2}{|c|}{0.09} & \multicolumn{2}{|c|}{0.10} & & & & & & \\
\hline Spec & c Energy MJkg-1 & & & & & & & & & & \\
\hline Net 1 & ergy & & & & & & & & & & \\
\hline
\end{tabular}

Table.8 The field capacity of various operations under partial mechanized and traditional methods

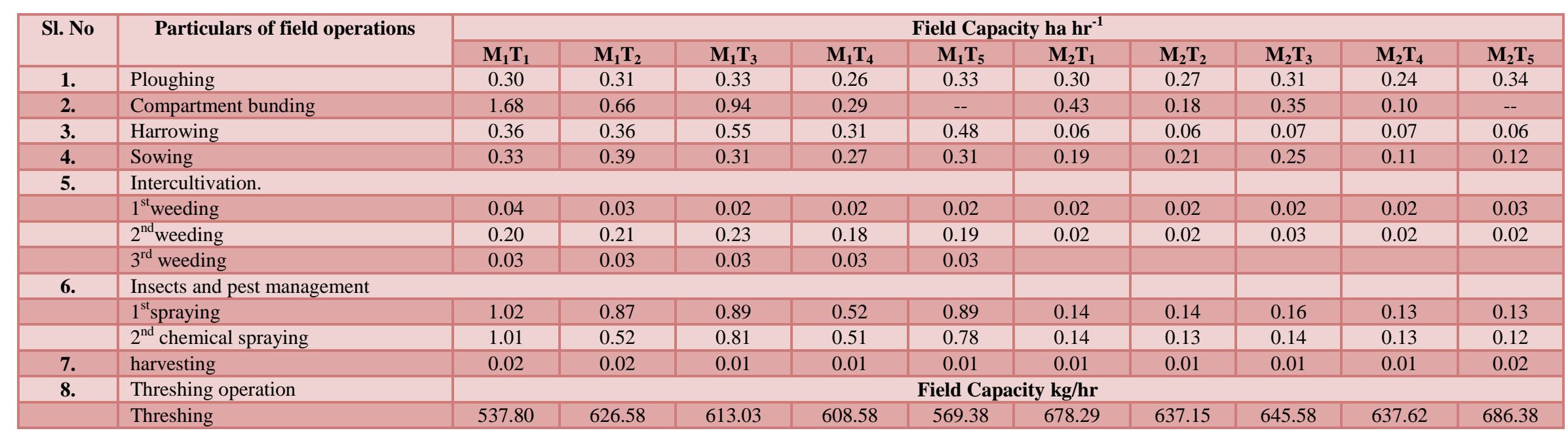


Table.9 Yield $\left(\mathrm{kg} \mathrm{ha}^{-1}\right)$, rainwater use efficiency $\left(\mathrm{kg} \mathrm{ha}^{-1} \mathrm{~mm}^{-1}\right)$, water productivity $\left(\mathrm{Rs} \mathrm{ha}^{-1} \mathrm{~mm}^{-1}\right)$, and moisture conservation efficiency $(\%)$

\begin{tabular}{|c|c|c|c|c|c|c|}
\hline Treatments & $\begin{array}{c}\text { Yield } \\
\text { kg ha }^{-1}\end{array}$ & $\begin{array}{l}\text { Stover yield } \\
\text { kg ha }^{-1}\end{array}$ & $\begin{array}{c}\text { Cost of cultivation } \\
\text { (Rs) }\end{array}$ & $\begin{array}{l}\text { Gross returns } \\
\text { (Rs) }\end{array}$ & $\begin{array}{l}\text { Net returns } \\
\quad(\mathrm{Rs})\end{array}$ & $\mathrm{BC}$ ratio \\
\hline $\mathbf{M}_{1} \mathbf{T}_{1}$ & $837.31(\mathrm{ab})$ & $1286.84(\mathrm{ab})$ & $14810(b c)$ & $31236(\mathrm{ab})$ & $16426(\mathrm{ab})$ & $2.11(\mathrm{ab})$ \\
\hline $\mathbf{M}_{1} \mathbf{T}_{2}$ & $920.73(\mathrm{ab})$ & $1440.19(\mathrm{ab})$ & 20394 (abc) & $34386(a b)$ & $13992(\mathrm{ab})$ & 1.69 (b) \\
\hline $\mathbf{M}_{1} \mathbf{T}_{3}$ & $803.07(\mathrm{ab})$ & $1232.95(b)$ & 13994 (bc) & $29957(\mathrm{ab})$ & $15963(\mathrm{ab})$ & $2.14(\mathrm{ab})$ \\
\hline $\mathbf{M}_{1} \mathbf{T}_{4}$ & 1341.02 (a) & 2102.84 (a) & $16976(\mathrm{abc})$ & 47255 (a) & 30279 (a) & 2.78 (a) \\
\hline $\mathbf{M}_{1} \mathbf{T}_{5}$ & 649.09 (b) & $1001.35(b)$ & $11438(\mathrm{c})$ & $24220(b)$ & $12782(b)$ & $2.12(\mathrm{ab})$ \\
\hline $\mathbf{M}_{2} \mathbf{T}_{1}$ & $946.80(\mathrm{ab})$ & $1441.79(\mathrm{ab})$ & $23315(a b)$ & $35301(\mathrm{ab})$ & $11986(b)$ & $1.51(b)$ \\
\hline $\mathbf{M}_{2} \mathbf{T}_{2}$ & $1019.44(\mathrm{ab})$ & $1577.74(\mathrm{ab})$ & 24681 (a) & $38048(a b)$ & 13367 (b) & 1.54 (b) \\
\hline $\mathbf{M}_{2} \mathbf{T}_{3}$ & 774.69 (b) & $1206.76(b)$ & 20776 (abc) & 28924 (b) & 8148 (b) & 1.39 (b) \\
\hline $\mathbf{M}_{2} \mathbf{T}_{4}$ & $1052.21(\mathrm{ab})$ & $1619.67(\mathrm{ab})$ & 25410 (a) & 39257 (ab) & $13847(a b)$ & 1.54 (b) \\
\hline $\mathbf{M}_{2} \mathbf{T}_{5}$ & $833.49(\mathrm{ab})$ & $1315.91(\mathrm{ab})$ & $16051(\mathrm{abc})$ & $31146(\mathrm{ab})$ & $15095(\mathrm{ab})$ & 1.94 (b) \\
\hline SEM \pm & 20.23 & 31.26 & 434.77 & 754.48 & 871.60 & 0.06 \\
\hline CD & 482.101 & 704.2 & 9846.14 & 17929.35 & 17330.9 & 0.84 \\
\hline
\end{tabular}

Table.10 Yield $\left(\mathrm{kg} \mathrm{ha}^{-1}\right)$, rainwater use efficiency $\left(\mathrm{kg} \mathrm{ha}^{-1} \mathrm{~mm}^{-1}\right)$, water productivity $\left(\mathrm{Rs} \mathrm{ha}^{-1} \mathrm{~mm}^{-1}\right)$, and moisture conservation efficiency $(\%)$

\begin{tabular}{|c|c|c|c|c|}
\hline Treatments & $\begin{array}{c}\text { Yield } \\
\left(\mathrm{kg} \mathrm{ha}^{-1}\right)\end{array}$ & $\begin{array}{c}\text { RWUE } \\
\left(\mathrm{kg} \mathrm{ha}^{-1} \mathrm{~mm}^{-1}\right)\end{array}$ & $\begin{array}{l}\text { Water Productivity } \\
\quad\left(\mathrm{kg} \mathrm{ha}^{-1} \mathrm{~mm}^{-1}\right)\end{array}$ & $\begin{array}{c}\text { Moisture Conservation } \\
\text { Efficiency }(\%)\end{array}$ \\
\hline $\mathrm{M}_{1} \mathrm{~T}_{1}$ & $837.31(\mathrm{ab})$ & $4.42 \mathrm{ab}$ & $164.92 \mathrm{ab}$ & $43.27 \mathrm{~cd}$ \\
\hline $\mathbf{M}_{1} \mathbf{T}_{2}$ & $920.73(\mathrm{ab})$ & $4.86 \mathrm{ab}$ & $181.55 \mathrm{ab}$ & $52.68 \mathrm{~b}$ \\
\hline $\mathbf{M}_{1} \mathbf{T}_{3}$ & $803.07(\mathrm{ab})$ & $4.24 \mathrm{~b}$ & $158.17 \mathrm{~b}$ & $51.05 \mathrm{~b}$ \\
\hline $\mathbf{M}_{1} \mathbf{T}_{4}$ & $1341.02(\mathrm{a})$ & $7.08 \mathrm{a}$ & $264.47 \mathrm{a}$ & $64.84 \mathrm{a}$ \\
\hline $\mathbf{M}_{1} \mathbf{T}_{5}$ & $649.09(b)$ & $3.43 \mathrm{~b}$ & $127.88 \mathrm{~b}$ & $45.33 \mathrm{c}$ \\
\hline $\mathbf{M}_{2} \mathbf{T}_{1}$ & $946.80(\mathrm{ab})$ & $5.00 \mathrm{ab}$ & $186.38 \mathrm{ab}$ & $54.80 \mathrm{~b}$ \\
\hline $\mathbf{M}_{2} \mathbf{T}_{2}$ & $1019.44(\mathrm{ab})$ & $5.38 \mathrm{ab}$ & $200.88 \mathrm{ab}$ & $40.85 \mathrm{~cd}$ \\
\hline $\mathbf{M}_{2} \mathbf{T}_{3}$ & 774.69 (b) & $4.09 \mathrm{~b}$ & $152.72 \mathrm{~b}$ & $63.38 \mathrm{a}$ \\
\hline $\mathbf{M}_{2} \mathbf{T}_{4}$ & $1052.21(\mathrm{ab})$ & $5.56 \mathrm{ab}$ & $207.27 \mathrm{ab}$ & $62.58 \mathrm{a}$ \\
\hline $\mathbf{M}_{2} \mathbf{T}_{5}$ & $833.49(\mathrm{ab})$ & $4.40 \mathrm{ab}$ & $164.45 \mathrm{ab}$ & $39.10 \mathrm{~d}$ \\
\hline SEM \pm & 20.23 & 0.11 & 3.98 & 0.14 \\
\hline CD & 482.101 & 2.54 & 94.66 & 3.71 \\
\hline
\end{tabular}


Fig.1 Study area (Regional Agricultural Research Station, Vijayapura (Karnataka)

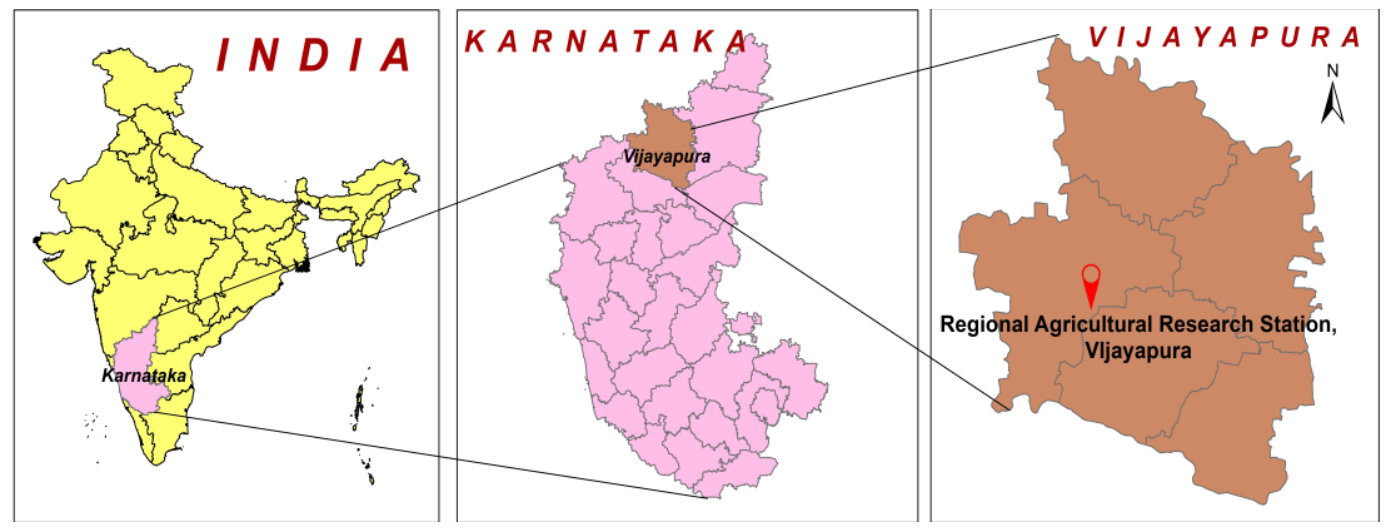

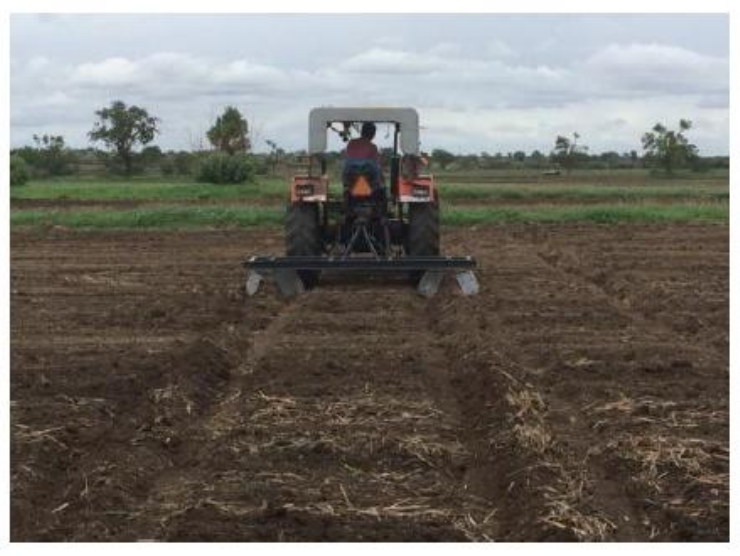

Figure 2: Compartment bunding using partial mechanized method

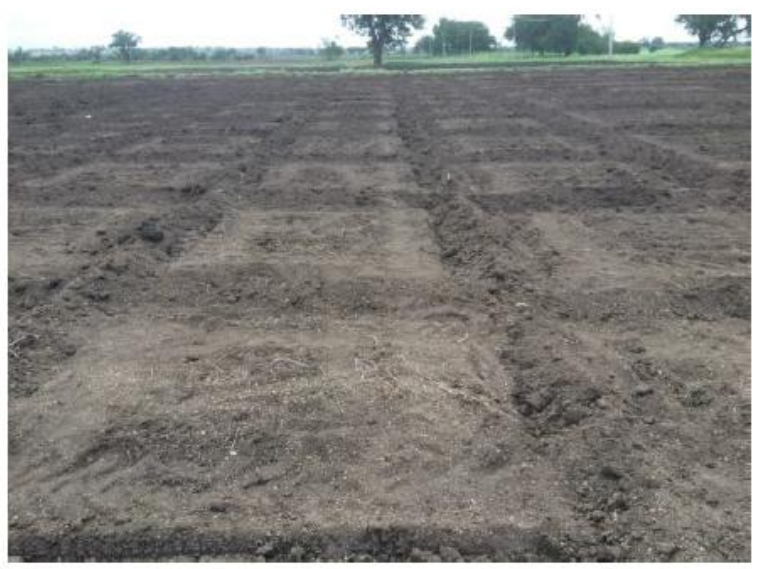

Figure 4 compartment bunding before rainfall

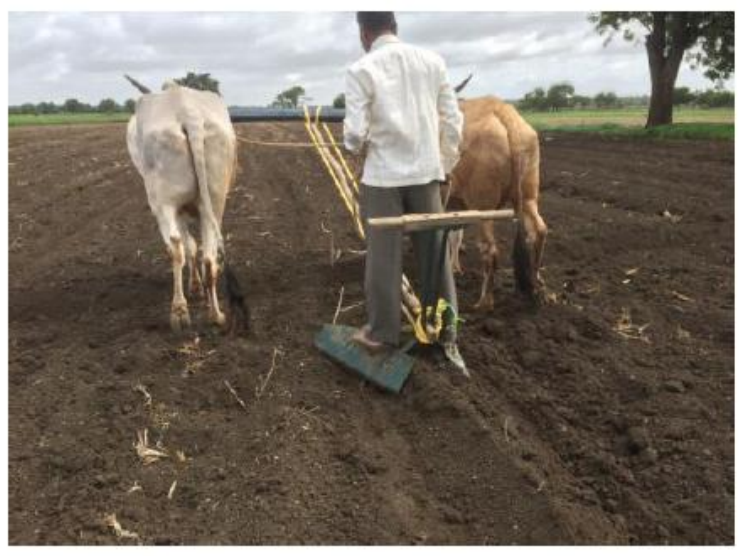

Figure 3: compartmental bunds using the traditional method

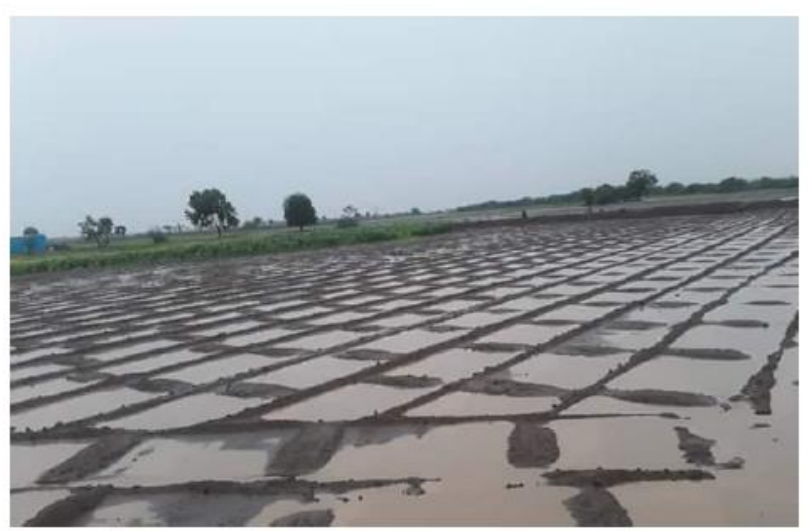

Figure 5 compartment bunding after rainfall 
Fig.6 Rainfall (mm) and evaporation during a) 2017, b) 2018, and c) 2019

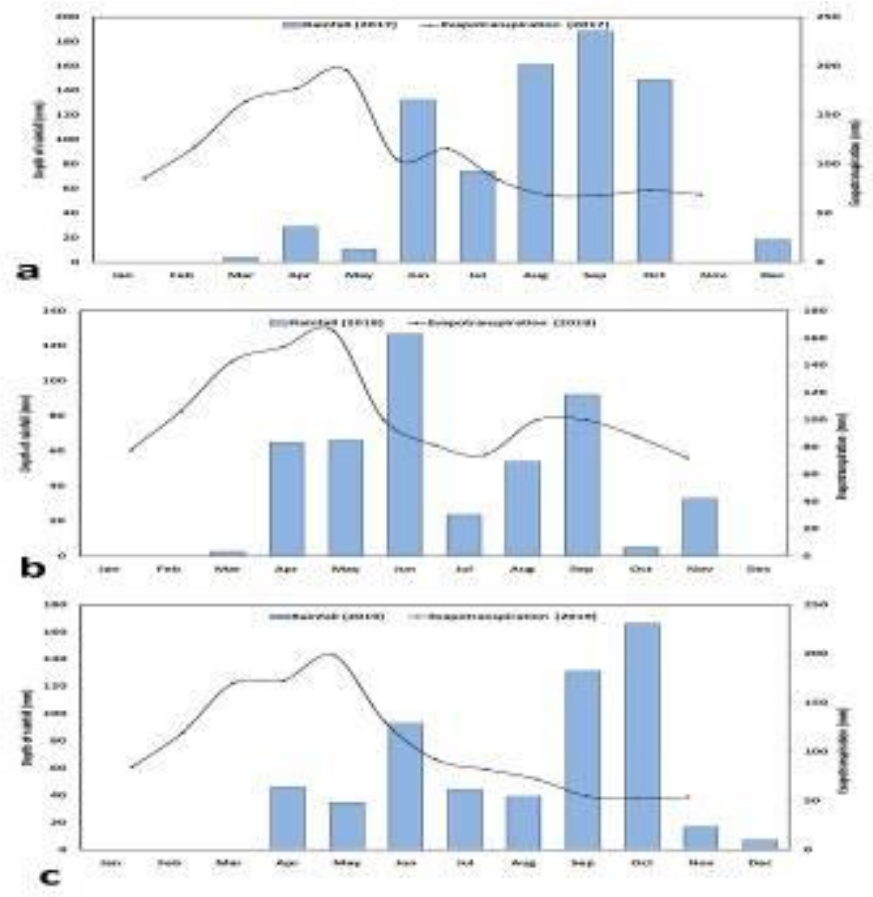

Fig.7 Sources-wise input used in a) $M_{1} T_{1}$, b) $M_{2} T_{1}$, c) $M_{1} T_{2}$, d) $M_{2} T_{2}$, e) $M_{1} T_{3}$, f) $M_{2} T_{3}$, g) $M_{1} T_{4}$, h) $\mathrm{M}_{2} \mathrm{~T}_{4}$, i) $\mathrm{M}_{1} \mathrm{~T}_{5}$, and j) $\mathrm{M}_{2} \mathrm{~T}_{5}$
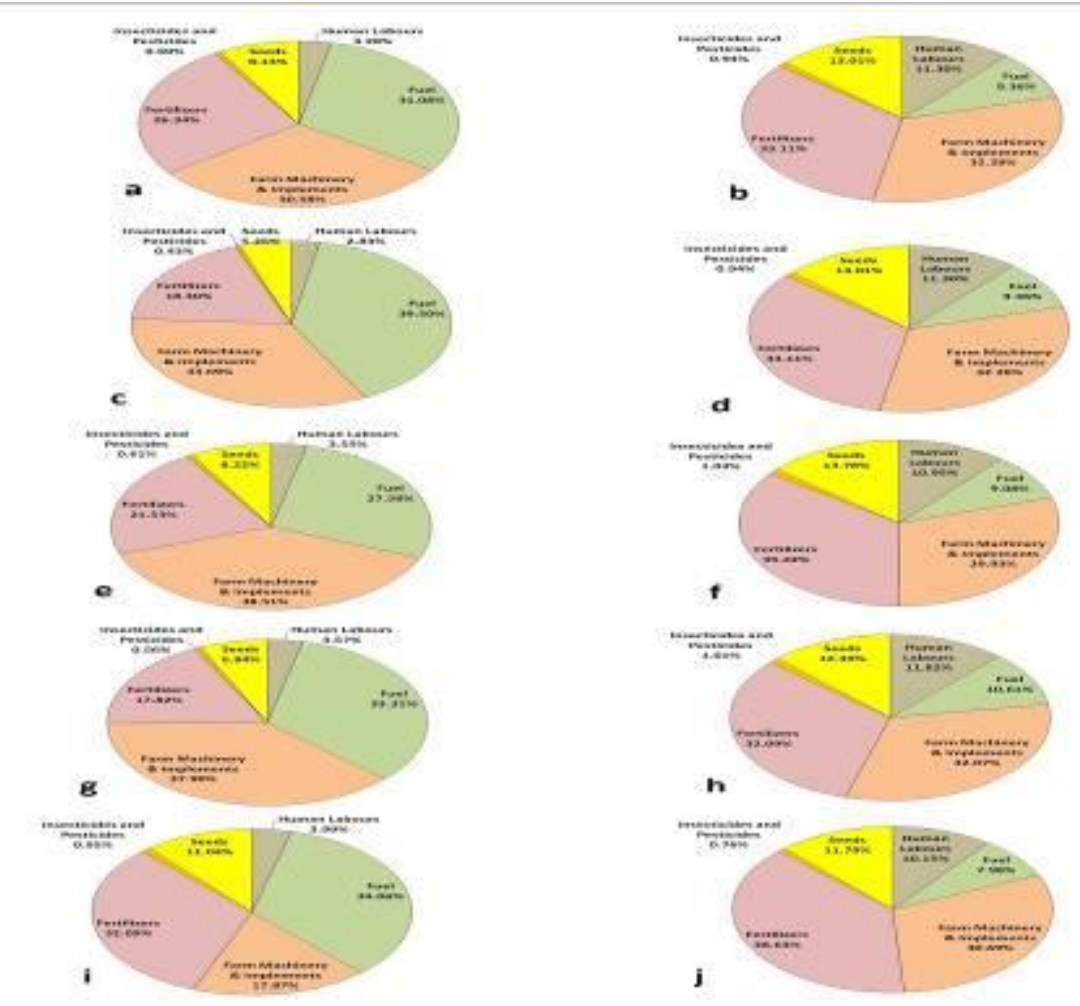
Fig.8 Operation-wise input used in a) $M_{1} T_{1}$, b) $M_{2} T_{1}$, c) $M_{1} T_{2}$, d) $M_{2} T_{2}$, e) $M_{1} T_{3}$, f) $M_{2} T_{3}$, g) $M_{1} T_{4}$, h) $\left.\mathrm{M}_{2} \mathrm{~T}_{4}, \mathrm{i}\right) \mathrm{M}_{1} \mathrm{~T}_{5}$, and j) $\mathrm{M}_{2} \mathrm{~T}_{5}$

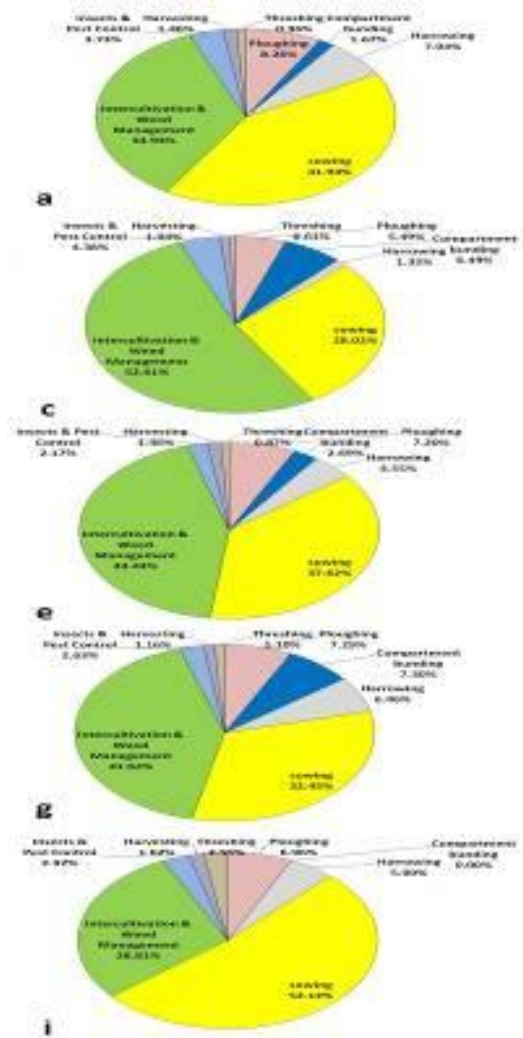

\section{Economics}

Assessment of partial mechanized and traditional cultivation and in-situ moisture conservation methods such as various sizes of compartment bunds were analyzed by using economic tools. these tools play a key role for the acceptance of aforesaid techniques by the farmers by seeing significant contribution of the methods as well as the sustainability of chickpea crop mainly depends on their performances of higher grain yield, byproduct, less input cost, less management and better market prices for the products under different climatic conditions (Patil et al., 2014).

The higher gross returns of Rs $47255.00 \mathrm{ha}^{-1}$ with a net return of Rs. $30279.00 \mathrm{ha}^{-1}$ and B: $C$ ratio of 2.78 was recorded under $M_{1} T_{4}$ of

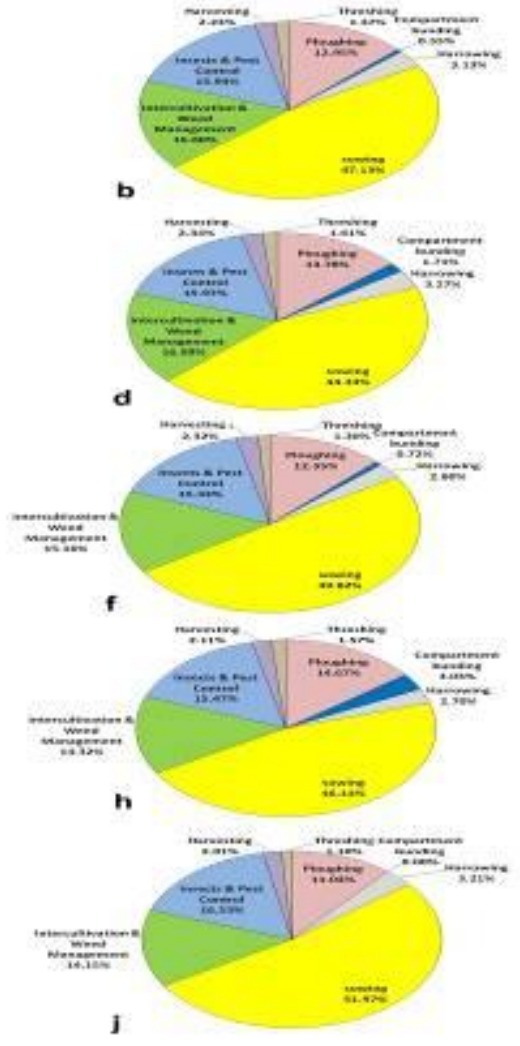

partial mechanized system. Whereas, lower gross returns of Rs. $24220.00 \mathrm{ha}^{-1}$, net returns Rs $12782.00 \mathrm{ha}^{-1}$, and $\mathrm{B}$ : C ratio of 2.12 was observed in $\mathrm{M}_{1} \mathrm{~T}_{5}$. On the other hand, the highest gross return of Rs. $39257.00 \mathrm{ha}^{-1}$, net returns Rs $13847.00 \mathrm{ha}^{-1}$ and $\mathrm{B}$ : C ratio of 1.54 was recorded in $\mathrm{M}_{2} \mathrm{~T}_{4}$ in traditional cultivation method and lower gross returns of Rs $28924.00 h a^{-1}$, net returns of Rs 8148.00 $h a^{-1}$, and B: C ratio of 1.39 was recorded in $\mathrm{M}_{2} \mathrm{~T}_{3}$. Statistical analysis indicated that a significant increase in gross return and net return was observed in $M_{1} T_{4}$ of the partial mechanized system as compared to the traditional method. In addition to this, a significantly higher input cost was observed in the traditional system. Overall a significantly higher input cost was observed in $\mathrm{M}_{2} \mathrm{~T}_{4}$ of the traditional cultivation method and a significant highest gross return, net 
returns, and $\mathrm{B}$ : $\mathrm{C}$ ratio was observed in $\mathrm{M}_{1} \mathrm{~T}_{4}$ of the partial mechanized system of cultivation. This is due to the reduction of input cost and use of farm mechanization in the various operations and thereby it increases the overall economic benefits in terms of gross return, the net return, and the $\mathrm{B}$ : $\mathrm{C}$ ratio. Also, the water productivity in terms of economic benefits as compared to the traditional system and significantly higher water productivity of Rs $264.47 \mathrm{ha}^{-1} \mathrm{~mm}^{-1}$ was observed in $\mathrm{M}_{1} \mathrm{~T}_{4}$ and lower water productivity of Rs $152.72 \mathrm{ha}^{-1} \mathrm{~mm}^{-1}$ was recorded in $\mathrm{M}_{2} \mathrm{~T}_{3}$.

Cultivation of chickpea along with the in-situ moisture conservation practices like the smaller size of compartment bund system i.e. $2 \times 2 m$ and $3 \times 3 m$ will help to increase the water productivity and use of farm mechanization to increase the field capacity during various farm operations and this helps to the farmer's to improve their standard of living by using mechanizations for in situ moisture conservation methods especially in Dry Land Agricultural regions. Therefore, that leads to improving the socio-economic status of the rainfed farmers.

In conclusion the conservation of in-situ soil moisture was an important parameter to increase crop productivity in rainfed areas of the Semi-Arid Tropical Region. The effect of compartmental bund of different sizes on Chickpea yield was assessed by using a partially mechanized method and traditional method of cultivation. The comportment bund size of $2 \times 2 \mathrm{~m}$ and $3 \times 3 \mathrm{~m}$ were found best practices for in-situ soil moisture conservation to increase grain yield, water use efficiency, and water productivity. Moreover, aforementioned compartment bund systems with the partial mechanized system will reduce input-cost, and thereby, it increases gross returns, net returns with higher B:C Ratio. In $2 \times 2 \mathrm{~m}$ compartment bund system with the partial mechanized method was observed that input energy of 12244.56 MJha1 and net output energy 26826.28 MJha-1 with an energy efficiency of 4.40, energy productivity of $0.13 \mathrm{~kg} \mathrm{MJ}-1$, the specific energy of 7.73 MJkg-1 and $3 \times 3 \mathrm{~m}$ compartment bund size along with partial mechanized system energy input was 13625.01 MJha-1 and net output energy 25800.84 MJha-1 with energy efficiency was 5.20 , energy productivity $0.15 \mathrm{~kg} \mathrm{MJ}-1$, the specific energy of $6.48 \mathrm{MJkg}-1$. In a $2 \times 2 \mathrm{~m}$ compartment bund system yield of 1341.02 kg ha-1 with input cost of Rs. 16976.00 ha-1 which gives the higher gross return of Rs. 47225.00 ha-1 and net return was Rs. 30279.00 ha-1 with a high B; C ratio of 2.78. The efficiency of the moisture conservation method was found highest of 64.84 percent with rainwater use efficiency of $7.08 \mathrm{kgha}-$ $1 \mathrm{~mm}-1$ and water productivity of Rs. 264.47 ha-1mm-1 in $2 \times 2 \mathrm{~m}$ compartment bund system under partial mechanized method. In addition, overall, 30 to 60 percentage of chickpea yield was achieved under $2 \times 2 \mathrm{~m}$ and $3 \times 3 \mathrm{~m}$ compartment bund systems under dryland condition will help farmers to continue cultivation practices in a sustainable manner in the rainfed region by using mechanization method along with in-situ moisture conservation methods.

\section{References}

Anonymous. 2011. Vision 2030, Indian Institute of Pulses Research, Kanpur. pp iii-vii.

Cutforth, H. W. et al., 2013, Comparing rooting characteristics and soil water withdrawal patterns of wheat with alternative oilseed and pulse crops grown in the semiarid Canadian prairie. Can. J. Soil Sci., 93: 147-160.

Demircan, V., Ekinci, K., Keener, H.M., Akbolat, D. and Ekinci, C. 2006. Energy and economic analysis of sweet cherry 
production in Turkey: a case study from Isparta province. Energy Conversion and Management 47:1761-9.

Erdal, G.K., Esengun, H. Erdal, O. Gunduz 2007. Energy use and economical analysis of sugar beet production in Tokat province of Turkey. Energy., 32: $35-41$.

Esengun, K., O. Gunduz, G. Erdal, 2007. Input-output energy analysis in dry apricot production of Turkey. Energy Consers Manage., 48:592-598.

Gan, Y. T., Zentner, R. P., Campbell, C. A., Biederbeck, V. O., Selles, F. and Lemke, R., Conserving soil and water with sustain-able cropping systems: research in the semiarid Canadian prairies. In 12th ISCO Conference, Beijing, 2002; http://www.pulsecanada.Com.

Geerts, S. and Raes, D. 2009. Deficit Irrigation as an On-Farm Strategy to Maximize Crop Water Productivity in Dry Areas. Agriultural Water Management, 96, 1275-1284.

http://dx.doi.org/10.1016/j.agwat.2009.0 4.009

Gowda, C. L. L., Srinivasan, S., Gaur, P. M. and Saxena, K. B., Enhancing the productivity and production of pulses in India. In Climate Change and Sustainable Food Security 2013 (eds Shetty, K., Ayyappan, S. and Swaminathan, M. S, National Institute of Advanced Studies, Bangalore and Indian Council of Agricul-tural Research, New Delhi, ISBN: 978-81-87663-76-8.

IIPR, Vision 2030. Indian Institute of Pulses Research, Kanpur, 2011, p. 42.

Kannan, N., Senthivel, T., Rayar, A. and Frank, M., 2010. Investigating water availability for introducing an additional crop yield in dry season on hill land at Rubirizi, Rwanda. Agricultural Water Management, 97(5), pp.623-634.

Kitani O. Energy and Biomass engineering. In: CIGR handbook of agricultural engineering. St. Joseph, MI:ASAE; 1999.p.330.

Mishra JP, Praharaj CS, Singh, K.K. 2012. Enhancing water use efficiency and production potential of chickpea and field pea through seed bed configurations and irrigation regimes in North Indian Plains. J Food Legumes 25(4):310-313

Nadarajan, N. 2013. Prospects and strategies for increasing pulses production in the potential states. In Training Manual 'Model Training Course on Management of Pest and Diseases in Pulse Crops' organized at IIPR, Kanpur, pp. 1-18.

Narain S, Singh SK, Singh L 2014.Impact of national food security mission-pulse on chickpea productivity in Hamirpur district of Uttar Pradesh. Indian Res J Ext Edu 14(3):24-27

Ozkan, B., Akcaoz, H. and Karadeniz, F. 2004. Energy requirement and economic analysis of citrus production in Turkey. Energy Conversion and Management 45:1821-30.

Patil S.L. and Sheelavantar. M.N. 2004. Effect of cultural practices on soil properties, moisture conservation and grain yield of winter sorghum (Sorghum bicolar L. Moench) in Semi-Arid Tropics of India. Agric. Water Manage.64: 49-67.

Patil, S., Loganandhan, N. and Ramesha, M., 2016. Evaluation of chickpea varieties under compartmental bunding in rainfed situation. Legume Research Legume Research, 39 (6) 2016: 890-895- An International Journal, (OF).

Patil, S., Loganandhan, N., Ramesha, M., Adhikary, P. and Channabasappa, K., 2016. Energy Consumption and Sensitivity Analysis of Rainfed Chickpea Production in Vertisols of Semi-arid Karnataka. Proceedings of the National Academy of Sciences, India Section B: Biological Sciences, 88(2), pp.685-694.

Rao, C.S., Steiner, J.L. and Mayeux, H.S. 2007. The Role of World's Agricultural 
Lands for Future Food Security in India, In Book on Challenges and Strategies for Dryland Agriculture (Ed. Barbarick, K.A. and Co-Ed. Rao, C.S. and John Ryan), pp. 1-10.

Reynolds, S., 1970. The gravimetric method of soil moisture determination Part I A study of equipment, and methodological problems. Journal of Hydrology, 11(3), pp.258-273

Rudragouda Chilur and Shiddanagouda Yadachi. 2017. Energy Audit of Maize Production System of Selected Villages of North Karnataka, India. Int. J. Curr. Microbiol. App. Sci. 6(8): 3564-3571. Doi:

http://doi.org/10.20546/ijcmas.2017.608. 427.

Salami, P. and Ahmadi, H., 2011. Energy inputs and outputs in a chickpea production system in Kurdistan, Iran. African Crop Science Journal, 18(2).

Shilpha, S.M., Soumya, T.M., Mamathashree, C.M., Girijesh, G.K., 2018. Energetics in Various Cropping Systems, Int. J. Pure App. Biosci. 6(4): 303-323 (2018). Doi: http://dx.doi.org/10.18782/23207051.6316.

Singh, H.P., Sharma., K.D., Subba Reddy, G. and Sharma. K.L. 2007. Dryland Agriculture in India, In Book on Challenges and Strategies for Dryland Agriculture (Ed. Barbarick, K.A. and Co-Ed. Rao, C.S. and John Ryan), pp. 67-92.
Somasundaram, J., Lakaria, B.L., Saha, R., Sinha, N.K., Jha, P., Chaudhary, R.S., Singh, R.K., Manadal, D., Hati, K.M., Ramesh, K., Vassanda, C., Biswas, A.K., Dey, P., Sammi Reddy, K. and Subba Rao, A. 2014. Management of stressed soils of dryland agriculture in semi-arid tropics-A review. Indian J. Soil Conserv., 42: 178-187.

Tripathi, J. 2010. Evaluation and promotion of resource conservation technologies in low land rice-wheat ecosystem. Agron. J. Nepal, 1: 28-39.

Turner, K., Georgiu, S., Clark, R., Brouwer, R. $\&$ Burke, J. 2004. Economic valuation of water resources in agriculture. from the sectoral to a functional perspective of water resources management. FAO Water Reports 27, Rome, FAO

Venkateswarlu B. and Shanker, A.K. 2009. Climate change and agriculture: Adaptation and mitigation strategies. Indian J.Agron.,54: 226-230.

Yousefi, M. and Damghani, A. M. 2012. Evaluation of energy flow and indicators of chickpea under rainfed condition in Iran. Int. J Farm. Allied Sci.,, 1(2), 5761.

Zwart, S.J. and Bastiaanssen, W.G.M. 2004 Review of Measured Crop Water Productivity Values for Irrigated Wheat, Rice, Cotton and Maize. Agricultural Water Management, 69, 115-133. http://dx.doi.org/10.1016/j.agwat.2004.0 4.007

\section{How to cite this article:}

Umarfarooque Momin, Ramesh Beerge, Basavaraj Jamakhandi, Maheshwar M. Shirahatti. 2021. Effect of Compartment Bunding Systems to Enhance the Productivity and Profitability Using Partial Mechanization for Chickpea under Semi Arid Region of Northern Karnataka. Int.J.Curr.Microbiol.App.Sci. 10(02): 2329-2346. doi: https://doi.org/10.20546/ijcmas.2021.1002.277 